\title{
"Validating brand identification and personality scale within the South African retail-banking context"
}

\begin{tabular}{|c|c|}
\hline AUTHORS & Marko van Deventer (iD) \\
\hline ARTICLE INFO & $\begin{array}{l}\text { Marko van Deventer (2021). Validating brand identification and personality scale } \\
\text { within the South African retail-banking context. Banks and Bank Systems, 16(4), } \\
\text { 1-10. doi:10.21511/bbs.16(4).2021.01 }\end{array}$ \\
\hline DOI & http://dx.doi.org/10.21511/bbs.16(4).2021.01 \\
\hline RELEASED ON & Monday, 04 October 2021 \\
\hline RECEIVED ON & Monday, 02 August 2021 \\
\hline \multirow[t]{2}{*}{ ACCEPTED ON } & Wednesday, 22 September 2021 \\
\hline & $(\mathrm{cc}) \overline{\mathrm{EY}}$ \\
\hline LICENSE & $\begin{array}{l}\text { This work is licensed under a Creative Commons Attribution } 4.0 \text { International } \\
\text { License }\end{array}$ \\
\hline JOURNAL & "Banks and Bank Systems" \\
\hline ISSN PRINT & $1816-7403$ \\
\hline ISSN ONLINE & $1991-7074$ \\
\hline PUBLISHER & LLC "Consulting Publishing Company "Business Perspectives" \\
\hline FOUNDER & LLC "Consulting Publishing Company "Business Perspectives" \\
\hline & 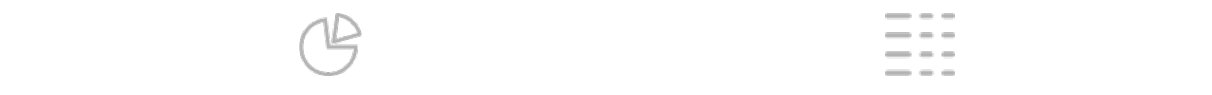 \\
\hline NUMBER OF REFERENCES & NUMBER OF FIGURES \\
\hline 53 & 3 \\
\hline
\end{tabular}

(c) The author(s) 2022. This publication is an open access article. 


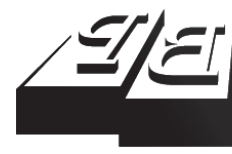

\section{BUSINESS PERSPECTIVES}

LLC "CPC "Business Perspectives" Hryhorii Skovoroda lane, 10, Sumy, 40022, Ukraine www.businessperspectives.org

Received on: $2^{\text {nd }}$ of August, 2021 Accepted on: 22nd of September, 2021 Published on: $4^{\text {th }}$ of October, 2021

(c) Marko van Deventer, 2021

Marko van Deventer, Ph.D., NorthWest University, South Africa.

\section{VALIDATING BRAND IDENTIFICATION AND PERSONALITY SCALE WITHIN THE SOUTH AFRICAN RETAIL- BANKING CONTEXT}

\begin{abstract}
While marketing experts agree that brand personality is important for brand identification, there is no evidence of a validated brand-identification-and-personality scale in the context of retail banking in South Africa. To address this literature gap, this study's purpose was to explain the process used to validate brand identification and personality within the retail-banking context of South Africa. A convenience sample of Generation Y banking consumers was selected, and a descriptive and single cross-sectional research design was followed. Self-administered questionnaires were used as a data collection tool and a sample size was chosen $(\mathrm{N}=235)$. Data analysis entailed descriptive and confirmatory factor analysis. The confirmatory factor analysis results validated brand identification and brand personality in retail banking as a five-factor structure that includes bank identification and brand personality dimensions such as successfulness, sophistication, sincerity and ruggedness. Furthermore, the results of the study indicate the internal consistency and composite reliability of the measurement model, as well as construct, convergent, discriminant and nomological validity. In addition, the measurement model revealed no signs of multicollinearity between the factors, and the model fit index values of IFI, TLI, CFI, SRMR and RMSEA showed a good fitting model. This study concluded that this five-factor model is a reliable and valid instrument of brand identification and personality in retail banking and is the first validated brand-identification-and-personality scale within the retail-banking context of South Africa.
\end{abstract}

Keywords measurement model, scale validation, confirmatory factor analysis, model fit

\section{JEL Classification G20, C20, G21}

\section{INTRODUCTION}

Retail banks operate in an environment that is fiercely competitive in nature (Arnaboldi \& Claeys, 2008). In addition, like many businesses, retail banks also face a number of challenges, such as expanding the operations of the business (Martins et al., 2014), increasing the share of the market (Arnaboldi \& Claeys, 2008), reducing operational costs (Martins et al., 2014) and strengthening the performance of a bank (Ernst \& Young, 2009), while trying to meet the needs of ever-demanding customers (Ernst \& Young, 2017). To overcome these challenges and remain competitive, retail banks are constantly looking for ways to gain new customers and uphold the loyalty of their existing customer base. For example, retail banks spend considerable resources on advertising, regularly innovate to stay relevant and continuously add banking products and services for improved banking efficiency (Hopkins, 2017). However, although these efforts might offer retail banks a competitive advantage, differentiation from other retail banks and financial institutions is important, which can be achieved through effective branding (Vahdati et al., 2016 cited in Bruwer \& Buller, 2005). 
It is essential to comprehend the symbolic meanings attached to brands (Bang et al., 2014; Carlson et al., 2009; Eren-Erdogmus et al., 2015), given the role that brands play in building relationships with the consumer and its influence on the business's long-term success (Tuškej et al., 2013). Literature suggests that through a better understanding of brand meanings and associations, businesses can pave the way forward for improved financial performance through brand loyalty (Eren-Erdogmus et al., 2015). Brand loyal consumers benefit businesses in several ways. For example, businesses can take advantage of reduced marketing costs and positive word-of-mouth. Businesses also benefit from repeat purchases and are in a better position to protect their consumer base in a highly competitive business environment (Tsai, 2011).

From a retail bank's perspective, a brand denotes the bank's culture, values, personality traits, as well as the product and service quality offered by the retail bank (Hopkins, 2017). Furthermore, the bank brand is a "set of signifiers which communicate the desired customer perceptions" of a bank. Moreover, "consumers with certain personality traits are drawn to brands influenced by the extent that they can identify with the values and traits which are being communicated" by the bank brand (Moura, 2021). As such, customers tend to pay attention to the personality of the retail bank brand when they find it challenging to evaluate the brand (Vahdati et al., 2016). Moreover, there is evidence in the literature that brand personality is a determinant of brand identification (Carlson et al., 2009). This relationship infers that retail banks should build a distinctive brand personality to allow for easier brand identification among customers. Therefore, it is imperative that businesses such as retail banks consider building a distinctive brand personality. Additionally, it is important that retail banks recognize and comprehend which brand personality dimensions consumers associate with their chosen retail bank, not only for better positioning of the retail bank brand, but also for increased brand awareness, strength and value in the highly competitive environment in which retail banks operate. To this end, it is important to have a validated brand-identification-and-personality scale within the retail-banking context, which does not currently exist in South Africa.

\section{LITERATURE REVIEW}

The South African retail-banking sector consists of five main retail bank brands. These brands are ABSA, Capitec, FNB, Standard Bank and Nedbank (BusinessTech, 2019). While each of these retail banks offers similar products and services, they differ in terms of their brand personality, which is described as a "set of human characteristics typically associated with a brand" (Aaker, 1997, p. 347). From the perspective of a consumer, the personality of a brand represents the type of individual the brand intends to be (Aaker \& Biel, 2009). Building a one-of-a-kind brand personality is an important consideration, given that "consumers often imbue brands with human characteristics" (Aaker, 1997, p. 347) and support brands that embody personality traits similar to theirs (Aaker, 1997).

Jennifer Aaker originally validated the brand personality scale. This scale comprises five brand personality dimensions, namely "sincerity, excitement, competence, sophistication and rugged- ness" (Eren-Erdogmus et al., 2015, p. 152 cited in Aaker, 1997). The sincerity dimension of brand personality refers to brands that are seen as "honest, genuine, cheerful, wholesome and down-toearth", whereas excitement describe brands that are seen as "daring, spirited, imaginative, cool, unique, contemporary and anti-establishment" (Guttmann, 2019). Brands that are viewed as competent have personality traits such as "reliable, responsible, trustworthy, intellect, success and confidence" (Guttmann, 2019), whereas sophistication refers to brands that are perceived as luxury and superior and that promote the lifestyle customers desire (Mullan, 2020 cited in Aaker, 1997). Rugged brands are characterized as powerful and outdoorsy (Mullan, 2020 cited in Aaker, 1997), as well as "hard-working, authentic, strong, muscular and high-quality" (Guttmann, 2019). These five dimensions of brand personality is widely applied in the marketing research field (Moura, 2021) and within various contexts, such as the apparel brand market (Eren-Erdogmus et al., 2015), dental care market (Thomas \& Sekar, 2008), computer brand 
market (Ariff et al., 2012) and automobile market (Sokhela, 2015).

Eren-Erdogmus et al. (2015, p. 157) found that "although Turkish Generation Y consumers associate the brand personality traits of sincerity, excitement, competence and sophistication with apparel brands, the personality dimension of ruggedness did not feature in this regard". In India, Thomas and Seker (2008) discovered that the dental care brand, Colgate, is associated with personality dimensions such as sincerity, excitement and competence among consumers. Ariff et al. (2012, p. 124) sampled computer users in Turkey and found that the sampled participants deem "sincerity, excitement, competence and ruggedness" as important computer brand personality traits. In the South African automobile market, Sokhela (2015) learnt that consumers from the Generation Y cohort associate brand personalities such as sophistication, competence and excitement with their chosen luxury sedan motor vehicle brand.

In addition to the traditional five personality dimensions, some studies include several other personalities that consumers might associate with a brand. Some of these personalities include classic, which are brands typically associated with personalities such as tradition and old fashions (Braunstein \& Ross, 2010 cited in Aiken \& Sukhdial, 2004), community driven, which are brands associated with personalities such as authentication (Alexander, 2008), inspiration (Motion et al., 2003) and service orientation (Gronroos, 1989), as well as successfulness, which are brands associated with efficiency and respect (Braunstein \& Ross, 2010). For example, Braunstein and Ross (2010) studied successfulness, classic and community driven as brand personalities in the sport management field and applied these two personalities to professional sport teams. However, because the community driven brand personality was found to be an unreliable measure in the Braunstein and Ross (2010) study, and given that the classic personality is not really fitting into the retail-banking context, this study opted for validated dimensions of brand personality, namely three original dimensions of brand personality, including sophistication, sincerity and ruggedness, as well as one additional personality trait, successfulness. These four brand personality dimensions were specifically included in this study, as the South African retail-banking industry is unique and should therefore be assessed as such. A broad search of the literature showed no study alike undertaken within the South African retail-banking context measuring these brand personality dimensions.

Like the apparel, dental care, computer and automobile markets, as well as various other markets, retail banks also use their unique brand personalities in an attempt to separate themselves from other retail banks and financial institutions alike (Hopkins, 2017) and subsequently build strong brand loyalty (Timberlake, 2013). Furthermore, retail banks could use their brand personalities to entice the market segments they intend to target (Mullan, 2020). In addition, retail banks use their unique brand personality to create and communicate noteworthy associations with the retail bank, including brand values, image and trustworthiness (Moura, 2021; Wilson \& Grant, 2013). When consumers associate with the brand personality of the retail bank, they do not only build robust relationships with the bank brand (Sung \& Kim, 2010), but also more easily identify with the retail bank (Carlson et al., 2009; Moura, 2021), which is imperative, given today's complex and globalised business environment ( $\mathrm{Hu}, 2020)$.

Brand identification is "founded on the social identity theory and allows consumers to have a positive attitude towards the brand based on personal values and characteristics" $(\mathrm{Hu}, 2020$, p. 2). Brand identification refers to "perceived oneness with the brand" (Stokburger-Sauer et al., 2013, p. 6) or "sense of belonging to a brand" (Punjaisri \& Wilson, 2011, p. 1526). Those consumers who exhibit higher brand identification levels are more inclined to be involved in pro-brand activities, such as displaying support for business goals and products, protecting the business's reputation and becoming brand loyal ( $\mathrm{He} \& \mathrm{Li}, 2011)$. Moreover, consumers who associate with a brand express themselves "in relation to the brand" and view the brand's achievements and defeats as their own. As such, brand identification denotes the extent to which a brand articulates and improves identity of consumers (Balaji et al., 2016). Bank identification, as it applies to this study, refers to consumers' degree of oneness with the 
bank brand $(\mathrm{Hu}, 2020)$. Literature suggests that there is a "relationship between brand identification and brand personality" (Carlson et al., 2009, p. 370), meaning that, from a retail-banking point of view, once consumers associate themselves with the perceived personality of a bank, they find it easier to identify with the bank. It is important that retail banks understand consumers' level of bank identification, as this will assist the retail bank in how to position the brand, communicate the brand and market the brand.

Given the link between identification with a brand and brand personality, it is also key that retail banks consider the influence of brand personalities on bank identification. A number of international studies confirm that "brand personality is a predictor of brand identification" (Carlson et al., 2009; Gammoh et al., 2014; Karjaluoto et al., 2016; Kuenzel \& Halliday, 2010; Polyorat, 2011). While the findings of these internationally published studies confirm the correlation between brand identification and a number of brand personalities, a broad online search of some of the largest databases of academic research displayed no evidence of a validated brand-identification-and-personality scale within the South African retail-banking context.

To fill this literature gap, this study's purpose was to explain the process to validate brand identification and brand personality as a five-factor structure consisting of bank identification and brand personality dimensions such as successfulness, sophistication, sincerity and ruggedness within the South African retail-banking context. The Generation Y banking consumer cohort was chosen as a sample and was considered a relevant sample to validate the brand-identification-and-personality scale for several reasons.

"The Generation Y cohort includes individuals born between 1986 and 2005" (Markert, 2004, p. 21). This generation is also referred to as the youth, millennials and the MTV Generation (Rahman \& Azhar, 2011). On a global scale, the Generation $\mathrm{Y}$ cohort accounts for about 32 percent of the world's population (Miller \& Lu, 2018). In South Africa, statistics indicate that Generation Y comprises nearly " 35 percent of the country's population" (Statistics South Africa, 2020). This co- hort's substantial size renders them a rewarding and noteworthy market for many sectors, including the retail-banking sector. This study also used Generation Y consumers as the sample, given their unique characteristics. For example, Generation Y consumers are opinion leaders and trendsetter among their peers (Bevan-Dye \& Akpojivi, 2016) and are perceived to be socially conscious and egocentric (Coelho \& Las Casas, 2013). These fickle and technologically astute (Osipow \& Sheehan, 2014) consumers tend to purchase brands that resembles their self-image and that are consistent with their values, thereby building a robust relationship with the brand (Lazarevic, 2012). Furthermore, Generation Y consumers view certain brands as prestigious tokens and status symbols. In addition, Generation $\mathrm{Y}$ consumers are inclined to purchase brands that are recommended by celebrities, media personalities, friends and social media influencers (Osipow \& Sheehan, 2014). Another important reason for using Generation Y consumers as the sample is their brand loyalty, that is, their brand loyalty tendencies remain unclear (Lazarevic, 2012), and literature suggests that these consumers' brand loyalty and commitment to a brand do not tend to last for a long period of time (Graywood, 2018). Therefore, it is important that retail banks differentiate themselves in terms of their brand personality to ensure that Generation Y consumers easily identify with their chosen retail bank. To this end, it is important to have a validated brand-identification-and-personality scale. As such, this study's purpose is to answer the research question phrased below:

Are brand identification and brand personality among Generation Y banking consumers a five-factor structure that includes bank identification and brand personality dimensions such as successfulness, sophistication, sincerity and ruggedness?

\section{METHOD}

A descriptive and single cross-sectional research design was applied in this study. This study's population of interest was Generation Y banking consumers within the age category of between 18 and 24 years, enrolled at two of South Africa's 
26 public higher education institutions (HEIs). Judgement sampling was selected to choose two Gauteng-based HEI campuses (one university of technology campus and one traditional university campus) from 26 public HEIs included in the frame of sampling. In terms of the data collection, after receiving approval, fieldworkers, using the mall-intercept survey technique, distributed 150 questionnaires at each campus to a convenience sample of voluntary participants. The sample size of 300 participants was deemed sufficient, given that the "measurement model consisted of fewer than seven latent factors, each of which had three variables" (Hair et al., 2010).

A survey self-administered questionnaire comprising a cover letter and two sections was developed for collecting the data. The cover letter clarified the study's purpose and promised the participants that their participation would be handled with due diligence and confidentiality. The first section requested the participants' demographic information. In line with the data required, the second section contained adapted scales from two international, previously validated studies. The brand identification scale (Swanson et al., 2003) was used to measure Generation Y banking consumers' bank identification, while the brand personality scale (Braunstein \& Ross, 2010) was used to measure these consumers' perceived bank brand personality traits. Each factor comprised three items and was measured using a six-point Likert-type scale, in which one denoted strongly disagree and six strongly agree.

Two IMB statistical packages were used to analyze the data, namely SPSS and AMOS, Versions 27 for Windows. Descriptive, reliability and validity, and correlation statistics, together with the diagnostics for collinearity and confirmatory factor analysis using the maximum likelihood approach, were part of the data analysis.

\section{RESULTS}

Fieldworkers distributed 300 self-administered questionnaires, of which 235 could be used for data analysis, resulting in a study response rate of 78 percent. The sampled participants' demographics are provided in Table 1.
Table 1. Demographic data

\begin{tabular}{|c|c|}
\hline Age & $\%$ \\
\hline 20 & 21.7 \\
\hline 19 & 19.6 \\
\hline 21 & 18.7 \\
\hline 18 & 15.7 \\
\hline 22 & 11.5 \\
\hline 23 & 10.6 \\
\hline 24 & 2.1 \\
\hline Gender & $\%$ \\
\hline Female & 50.6 \\
\hline Male & 49.4 \\
\hline Province of origin & $\%$ \\
\hline Gauteng & 40.9 \\
\hline Eastern Cape & 20.9 \\
\hline Limpopo & 16.2 \\
\hline Free State & 7.7 \\
\hline Mpumalanga & 6.0 \\
\hline North West & 4.3 \\
\hline KwaZulu-Natal & 3.8 \\
\hline Northern Cape & 0.4 \\
\hline Retail bank & $\%$ \\
\hline Capitec & 45.5 \\
\hline ABSA & 19.6 \\
\hline FNB & 15.3 \\
\hline Standard Bank & 11.1 \\
\hline Nedbank & 8.5 \\
\hline Mother language & $\%$ \\
\hline isiXhosa & 23.8 \\
\hline Sesotho & 17.4 \\
\hline Afrikaans & 15.3 \\
\hline isiZulu & 10.6 \\
\hline Sepedi & 7.7 \\
\hline Xitsonga & 7.7 \\
\hline Setswana & 7.2 \\
\hline Tshivenda & 5.5 \\
\hline SiSwati & 3.0 \\
\hline English & 1.7 \\
\hline
\end{tabular}

As indicated in Table 1, the sample included more participants aged 20, followed by participants aged 19 and 21. Moreover, the sample consisted of slightly more females than males. Furthermore, most of the sample indicated Gauteng as their origin province, followed by the Eastern Cape Province, and most of the sampled participants indicated isiXhosa and Sesotho as their mother-tongue language. In terms of a banking institution, the majority of the participants bank with Capitec, followed by those banking with ABSA and FNB.

For each latent factor, descriptive statistics (mean $=\bar{X}$; standard deviation $=\sigma$ ), Cronbach's alphas (a) and coefficients of Pearson's product-moment 
Table 2. SPSS output

\begin{tabular}{|c|c|c|c|c|c|c|c|c|c|}
\hline Latent factors & $\overline{\mathbf{x}}$ & $\sigma$ & $\alpha$ & $F 1$ & $F 2$ & $F 3$ & $F 4$ & TV & VIF \\
\hline Bank identification (F1) & 3.72 & 1.38 & 0.78 & - & - & - & - & 0.96 & 1.05 \\
\hline Successfulness (F2) & 4.98 & 0.78 & 0.84 & $0.18^{*}$ & - & - & - & 0.56 & 1.78 \\
\hline Sophistication (F3) & 4.98 & 0.76 & 0.76 & $0.11^{*}$ & $0.57^{*}$ & - & - & 0.55 & 0.81 \\
\hline Sincerity (F4) & 4.93 & 0.84 & 0.81 & $0.19^{*}$ & $0.62^{*}$ & $0.65^{*}$ & - & 0.53 & 1.90 \\
\hline Ruggedness (F5) & 4.57 & 0.88 & 0.66 & $0.15^{*}$ & $0.40^{*}$ & $0.44^{*}$ & $0.47^{*}$ & 0.74 & 1.35 \\
\hline
\end{tabular}

Note: ${ }^{*} p \leq 0.05$ (2-tailed).

correlation were calculated. The Cronbach's alpha value is indicative of internal-consistency reliability, whereas the correlation coefficients point to the relationships between the latent factors and the measurement theory's nomological validity. Moreover, collinearity diagnostics were performed to assess whether there is multicollinearity between the factors.

Descriptive statistics in Table 2 show that each latent factor returned a mean value that exceeds 3.5. In terms of the Cronbach alphas, values above 0.6 were recorded for each latent factor, which suggests acceptable internal-consistency reliability (Zikmund \& Babin, 2013). The correlation analysis showed that a statistically significant positive relationship ( $p \leq 0.05)$ was evident between each pair of latent factors, which suggests the measurement theory's nomological validity (Malhotra, 2010). Moreover, since the strongest coefficient $(r$ $=0.71$ ) was below the suggested 0.90 cut-off level, the possibility of multicollinearity is eliminated (Pallant, 2013). To assess more subtle forms of multicollinearity, the diagnostics for collinearity were run. With tolerance values (TV) above 0.10 , ranging from 0.53 to 0.96 , and an average variance inflation factor (VIF) value of 1.38 , which is well below the suggested 10 cut-off level (Pallant, 2010), no serious multicollinearity issues were detected. With no serious multicollinearity between the latent factors, together with the nomological validity of the measurement theory established, a measurement model was proposed.

Using the maximum likelihood approach, confirmatory factor analysis was performed for a specified five-factor measurement model, which included bank identification, successfulness, sophistication, sincerity and ruggedness. Each latent factor contained three indicators. To identify the model, each of the five latent factors' first loading was set at 1.0. In doing this, 135 distinct sample moments were derived with 63 distinct parameters to be estimated, equating to 72 degrees of freedom $(d f)$ based on an over-identified model. In addition, a chi-square value of $114.23(p=0.001)$ was produced.

To check for any problematic estimates, the measurement model was assessed in terms of standardized factor loadings greater than 1.0 or less than -1.0. In addition, negative error variances (Heywood cases) were checked (Hair et al., 2010). To evaluate composite reliability (CR) and construct validity, the CR, average variance extracted (AVE) and heterotrait-monotrait (HTMT) values were calculated. In addition, the correlation coefficients for each latent factor and its observed variable were computed. The measurement model estimates are reported in Table 3.

The results delineated in Table 3 indicate that the estimates were not problematic and that there was a statistically significant $(p \leq 0.01)$ relationship between each latent factor and its observed variable. With CR values exceeding 0.70 and AVE values above $0.50, \mathrm{CR}$ and convergent validity are confirmed (Malhotra, 2010; Hair et al., 2010). Concerning discriminant validity, the "HTMT values did not exceed 0.85 , which point towards discriminant validity" (Henseler et al., 2015, p. 127). There is evidence of construct validity given the combination of convergent and discriminant validity together with the nomological validity confirmed in Table 2 (Malhotra, 2010).

Fit to the model was evaluated using "the incremental fit index (IFI), Tucker-Lewis index (TLI), comparative fit index (CFI), the standardized root mean residual (SRMR), the root mean square of approximation (RMSEA), and the chi-square statistic" (Van Deventer, 2018, p. 191). Acceptable fit to the model is achieved when the chi-square value is non-significant and when the IFI, TLI and CFI values ex- 
Table 3. Confirmatory factor analysis

\begin{tabular}{|c|c|c|c|c|c|c|c|c|}
\hline \multirow{2}{*}{ Latent factors } & \multirow{2}{*}{$\begin{array}{c}\text { Standardized } \\
\text { loading estimates }\end{array}$} & \multirow{2}{*}{$\begin{array}{c}\text { Error variance } \\
\text { estimates }\end{array}$} & \multirow{2}{*}{ CR } & \multirow{2}{*}{ AVE } & \multicolumn{4}{|c|}{ HTMT } \\
\hline & & & & & $F 1$ & $F 2$ & $F 3$ & $F 4$ \\
\hline \multirow{3}{*}{$\begin{array}{l}\text { Bank identification } \\
(F 1)\end{array}$} & 0.72 & 0.70 & 0.78 & 0.54 & - & - & - & - \\
\hline & 0.74 & 0.79 & - & - & - & - & - & - \\
\hline & 0.74 & 0.77 & - & - & - & - & - & - \\
\hline \multirow{3}{*}{$\begin{array}{l}\text { Successfulness } \\
(F 2)\end{array}$} & 0.76 & 0.60 & 0.79 & 0.55 & 0.23 & & - & - \\
\hline & 0.72 & 0.59 & - & - & - & - & - & - \\
\hline & 0.75 & 0.52 & - & - & - & - & - & - \\
\hline \multirow{3}{*}{$\begin{array}{l}\text { Sophistication } \\
(F 3)\end{array}$} & 0.78 & 0.69 & 0.77 & 0.53 & 0.14 & 0.71 & - & - \\
\hline & 0.79 & 0.73 & - & - & - & - & - & - \\
\hline & 0.59 & 0.69 & - & - & - & - & - & - \\
\hline \multirow{3}{*}{$\begin{array}{l}\text { Sincerity } \\
(F 4)\end{array}$} & 0.72 & 0.75 & 0.80 & 0.57 & 0.24 & 0.76 & 0.84 & \\
\hline & 0.81 & 0.67 & - & - & - & - & - & - \\
\hline & 0.72 & 0.62 & - & - & - & - & - & - \\
\hline \multirow{3}{*}{$\begin{array}{l}\text { Ruggedness } \\
(F 5)\end{array}$} & 0.89 & 0.54 & 0.79 & 0.57 & 0.20 & 0.55 & 0.64 & 0.67 \\
\hline & 0.85 & 0.57 & - & - & - & - & - & - \\
\hline & 0.50 & 0.59 & - & - & - & - & - & - \\
\hline \multirow{3}{*}{ Correlations } & $F 1 \rightarrow F 2: 0.23$ & $F 1 \rightarrow F 3: 0.16$ & \multicolumn{3}{|c|}{$F 1 \rightarrow F 4: 0.24$} & \multicolumn{3}{|c|}{$F 1 \rightarrow F 5: 0.14$} \\
\hline & $F 2 \rightarrow F 3: 0.78$ & $F 2 \rightarrow F 4: 0.82$ & \multicolumn{3}{|c|}{$F 2 \rightarrow F 5: 0.50$} & \multicolumn{3}{|c|}{$F 3 \rightarrow F 4: 0.85$} \\
\hline & $F 3 \rightarrow F 5: 0.55$ & $F 4 \rightarrow F 5: 0.62$ & \\
\hline
\end{tabular}

ceed 0.90 . In addition, the RMSEA value should be equal to or less than 0.08 (Malhotra, 2010), whereas the SRMR value should not exceed 0.1 (Hair et al., 2010). While the model of measurement achieved a significant chi-square value of 114.23 with 72 degrees of freedom (df), all other fit measures indicate good model fit with $I F I=0.97, T L I=0.96, C F I=$ $0.97, S R M R=0.04$ and $R M S E A=0.05$.

The measurement model specified in this study not only exhibited good model fit, but also acceptable internal-consistency and CR, as well as nomological, convergent, discriminant and construct validity. As such, a structural model may be tested. As per the literature, the structural model will assess whether the brand personality dimensions of successfulness, sophistication, sincerity and ruggedness have a direct positive influence on bank identification.

\section{DISCUSSION}

This study's results indicate that the sampled participants identify with their bank and associate the brand personality dimensions of successfulness, sophistication, sincerity and ruggedness with their chosen retail bank. That is, Generation $Y$ consumers perceive their chosen retail bank as high performing and efficient, trendy and up-todate, friendly and down-to-earth, as well as bold and daring. Moreover, the correlation analysis shows that the participants mostly associate the brand personality dimensions of successfulness and sincerity with their chosen retail banks. In addition, the specified measurement model revealed no problematic estimates, demonstrated composite reliability and showed evidence of convergent and discriminant, as well as construct validity. Furthermore, the measurement model exhibited good model fit. As such, retail banks are advised to use this validated brand-identification-and-personality scale to determine the likely influence of the brand personality dimensions of successfulness, sophistication, sincerity and ruggedness on bank identification.

This study is not without limitations. For example, it relied on a self-reporting measuring instrument instead of observations, which may limit representation of the sample participants. Furthermore, a convenience sample was employed to survey participants. As such, when generalizing the results to the whole Generation Y banking consumer segment, great care should be taken. Moreover, this study's sample was limited in terms of geographical location. In addition, Generation Y banking customers from only two HEI campuses participated in this study. Therefore, this study could be carried out on a larger scale in the future. Other future research opportunities include a longitudinal study as well as qualitative studies. 


\section{CONCLUSION}

The purpose of this study was to test whether brand identification and brand personality within a retail-banking context are a five-factor structure. Using a Generation Y banking consumer sample, the confirmatory factor analysis results validated that bank identification and brand personality are a five-factor structure that comprises bank identification, as well as the dimensions of brand personality, namely successfulness, sophistication, sincerity and ruggedness. Each of the latent factors recorded acceptable internal-consistency reliability and there was no serious multicollinearity between the factors. Moreover, the nomological validity of the theory of measurement was established through correlation analysis. In addition, the measurement model showed evidence of acceptable CR as well as construct, convergent and discriminant validity. Lastly, the model fit indices of IFI, TLI, CFI, SRMR and RMSEA indicate good model fit. Thus, the results of this study concluded that this five-factor model is a valid and reliable measure of brand identification and brand personality and is regarded as the first validated brand identification and personality scale within the South African retail-banking context. Retail banks are advised to use this instrument to better understand which brand personality traits are important to their market segments, as well as each segment's level of bank identification.

\section{AUTHOR CONTRIBUTIONS}

Conceptualization: Marko van Deventer.

Data curation: Marko van Deventer.

Formal analysis: Marko van Deventer.

Investigation: Marko van Deventer.

Methodology: Marko van Deventer.

Project administration: Marko van Deventer.

Writing - original draft: Marko van Deventer.

Writing - reviewing \& editing: Marko van Deventer.

\section{REFERENCES}

1. Aaker, D., \& Biel, A. (2009). Brand Equity \& Advertising: Advertising's Role in Building Strong Brands. New York: Psychology Press: Taylor \& Francis. https://doi org/10.4324/9781315799537

2. Aaker, J. L. (1997). Dimensions of brand personality. Journal of Marketing Research, 34(3), 347-356. https://doi. org/10.1177/002224379703400304

3. Aiken, D., \& Sukhdial, A. (2004). Exploring the old school concept: Adding definition to a "new" market segmentation dimension. Sport Marketing Quarterly, 13(2), 73-81. Retrieved from https://www.semanticscholar. org/paper/Exploring-the-oldschool-concept $\% 3 \mathrm{~A}$-adding-definition-Aiken-Sukhdial/ed2d903ffaa065799c9215b386418330fa395f3e

4. Alexander, N. (2008). Brand authentication: Creating and maintaining brand auras. European Journal of Marketing, 43(3/4), 551-562. https://doi. org/10.1108/03090560910935578

5. Ariff, M. S. B. M., Lim, O. T., \& Ismail, K. (2012). Determination of brand personality dimensions for a laptop computer using Aaker's brand personality scale. Review of Integrative Business and Economics Research, 1(1), 114-125. Retrieved from https://sibresearch.org/ uploads/2/7/9/9/2799227/riber2012-117_114-125.pdf

6. Arnaboldi, F., \& Claeys, P. (2008). Internet banking in Europe: a comparative analysis (Working Papers No. 2008/11). Research Institute of Applied Economics. Retrieved from http://www. ub.edu/irea/working_papers/2008/200811.pdf
7. Balaji, M. S., Roy, S. K., \& Sadeque, S. (2016). Antecedents and consequences of university brand identification. Journal of Business Research, 69(8), 30233032. https://doi.org/10.1016/j. jbusres.2016.01.017

8. Bang, H., Lee, S., \& Swart, K. (2014). Predicting volunteers' intention to return: an examination of brand personality, prestige, and identification of sporting events. Event Management, 18(2), 169183. Retrieved from https:// scholarworks.iupui.edu/handle/1805/5076

9. Bevan-Dye, A. L., \& Akpojivi, U. (2016). South African Generation Y students' selfdisclosure on Facebook. South African Journal of Psychology, 46(1), 114-129. https://doi. org/10.1177/0081246315602645 
10. Braunstein, J. R., \& Ross, S. D. (2010). Brand personality in sport: dimension analysis and general scale development. Sport Marketing Quarterly, 19(1), 8-16. Retrieved from https://experts. umn.edu/en/publications/brandpersonality-in-sport-dimensionanalysis-and-general-scale-d

11. Bruwer, J., \& Buller, C. (2005). Country-of-origin brand preferences and associated knowledge levels of Japanese wine consumers. Journal of Product and Brand Management, 25(1), 307-316. http://dx.doi. org/10.1108/10610421211253605

12. BusinessTech. (2019). Battle of the banks: South Africa's big 5 banks compared. Retrieved from https://businesstech.co.za/news/ banking/339319/battle-of-thebanks-south-africas-big-5-bankscompared/

13. Carlson, B. D., Donavan, D. T., \& Cumiskey, K. J. (2009). Consumer-brand relationships in sport: brand personality and identification. International Journal of Retail \& Distribution Management, 37(4), 370-384. https://doi. org/10.1108/09590550910948592

14. Eren-Erdogmus, I., Cobanoglu, E., \& Budeyri-Turan, I. (2015). Exploring dimensions of brand personality for Generation $\mathrm{Y}$ in the apparel market: the case of Turkey. Journal of Global Fashion Marketing, 6(2), 150-161. https:// doi.org/10.1080/20932685.2014. 999010

15. Ernst \& Young. (2009). Mobile money: an overview for global telecommunications operators. Retrieved from https://ru.scribd. com/document/160947666/ Ernst-Young-Mobile-Money15-10-09-Single-View

16. Ernst \& Young. (2017). Global banking outlook 2017: uncertainty is no excuse for inaction. Retrieved from https://eyfinancialservicesthoughtgallery.ie/wp-content/uploads/2017/03/EY-global-bankingoutlook-2017.pdf

17. Gammoh, B. S., Mallin, M. L., \& Pullins, E. B. (2014). The impact of salesperson-brand personality congruence on salesperson brand identification, motivation and performance outcomes. Journal of Product \& Brand Management, 23(7), 543-553. https://doi. org/10.1108/JPBM-10-2013-0434

18. Graywood, M. (2018). How brand loyalty differs among the generations. Retrieved from https://modernrestaurantmanagement.com/how-brand-loyaltydiffers-among-the-generations/

19. Gronroos, C. (1989). Defining marketing: A market-oriented approach. European Journal of Marketing, 23(1), 5260. https://doi.org/10.1108/ EUM0000000000541

20. Guttmann, B. (2019). Explaining the five dimensions of brand personality. Retrieved from https:// nativesgroup.com/marketing/ explaining-the-five-dimensionsof-brand-personality/

21. Hair, J. F., Black, W. C., Babin, B. J., \& Anderson, R. E. (2010). Multivariate data analysis: A global perspective (7th ed.). New Jersey: Pearson Prentice Hall. Retrieved from https://www.pearson.com/ uk/educators/higher-educationeducators/program/Hair-Multivariate-Data-Analysis-GlobalEdition-7th-Edition/PGM916641. html

22. He, H., \& Li, Y. (2011). CSR and service brand: The mediating effect of brand identification and moderating effect of service quality. Journal of Business Ethics, 100(4), 673-688. https://doi. org/10.1007/s10551-010-0703-y

23. Henseler, J., Ringle, C. M., \& Sarstedt, M. (2015). A new criterion for assessing discriminant validity in variancebased structural equation modeling. Journal of the Academy of Marketing Science, 43(1), 115135. https://doi.org/10.1007/ s11747-014-0403-8

24. Hopkins, J. (2017). Branding in Banking: 5 Reasons Strong Brands Win. Retrieved from https://blog. ipswitch.com/branding-in-banking-5-reasons-strong-brands-win

25. Hu, J. (2020). How Consumer Citizenship Behavior and Intrinsic
Motivation Influences Consumer Brand Identification (Master's Thesis). Concordia University, Montreal, Quebec, Canada. Retrieved from https://spectrum. library.concordia.ca/986977/1/ Hu_MSc_F2020.pdf

26. Karajaluoto, H., Munnukka, J., \& Salmi, M. (2016). How do brand personality, identification, and relationship length drive loyalty in sports? Journal of Service Theory and Practice, 26(1), 50-71. https:// doi.org/10.1108/JSTP-09-20140206

27. Kuenzel, S., \& Halliday, S.V. (2010). The chain of effects from reputation and brand personality congruence to brand loyalty: the role of brand identification. Journal of Targeting, Measurement and Analysis for Marketing, 18(3/4), 167-176. https://doi. org/10.1057/jt.2010.15

28. Lazarevic, V. (2012). Encouraging brand loyalty in fickle Generation Y consumers. Young Consumers: Insight and Ideas for Responsible Marketers, 13(1), 45-61. https://doi. org/10.1108/17473611211203939

29. Malhotra, N. K. (2010). Marketing research: An applied orientation. (6th ed.). New Jersey: Pearson Prentice-Hall. Retrieved from https://www.pearson.com/us/ higher-education/program/Malhotra-Marketing-Research-AnApplied-Orientation-6th-Edition/ PGM201157.html

30. Markert, J. (2004). Demographics of age: generational and cohort confusion. Journal of Current Issues and Research in Advertising, 26(2), 11-25. https://doi.org/10.10 80/10641734.2004.10505161

31. Martins, C., Oliveira, T., \& Popovič, A. (2014).

Understanding the Internet banking adoption: a unified theory of acceptance and use of technology and perceived risk application. International Journal of Information Management, 34(1), 1-13. https://doi.org/10.1016/j. ijinfomgt.2013.06.002

32. Miller, L., \& Lu, W. (2018). Gen $Z$ Is Set to Outnumber Millennials Within a Year. Retrieved from https://www.bloombergquint. 
com/global-economics/gen-z-tooutnumber-millennials-within-ayear-demographic-trends

33. Motion, J., Leitch, S., \& Brodie, R. (2003). Equity in corporate co-branding: The case of adidas and the All Blacks. European Journal of Marketing, 37(7/8), 1080-1094. https://doi. org/10.1108/03090560310477672

34. Moura, F.T. (2021). Brand Personality: Understanding Aaker's Dimension Model. Retrieved from https://liveinnovation.org/brandpersonality-understanding-aakers5-dimension-model/

35. Mullan, E. (2020). 5 Companies Who Nailed Their Brand Personality. Retrieved from https://blog.hurree.co/blog/5companies-who-nailed-theirbrand-personality

36. Osipow, A., \& Sheehan, K. (2014). How Gens $X$ and $Y$ relate to the brands in their lives. Retrieved from https://www.quirks.com/ articles/how-gens- $\mathrm{X}$-and-y-relateto-the-brands-in-their-lives

37. Pallant, J. (2010). SPSS survival manual: A step by step guide to data analysis using SPSS. England: Open University Press.

38. Pallant, J. (2013). SPSS survival manual: A step by step guide to data analysis using the IBM SPSS (5th ed.). Berkshire: McGraw-Hill.

39. Polyorat, K. (2011). The influence of brand personality dimensions on brand identification and word-of-mouth: the case study of a university brand in Thailand. Asian Journal of Business Research, 1(1), 54-69. https://doi. org/10.14707/ajbr.110004

40. Punjaisri, K., \& Wilson, A. (2011). Internal branding process: key mechanisms, outcomes and moderating factors. European Journal of Marketing, 45(9/10), 1521-1537. https://doi. org/10.1108/03090561111151871

41. Rahman, S., \& Azhar, S. (2011). Xpressions of generation Y: perceptions of the mobile phone service industry in Pakistan. Asia Pacific Journal of Marketing and Logistics, 23(1), 91-107. https://doi. org/10.1108/13555851111100012
42. Sokhela, P. N. (2015). Brand personality perceptions of luxury sedan motor vehicles amongst the South African Generation Y cohort (Master's Thesis). North-West University. Retrieved from http:// dspace.nwu.ac.za/bitstream/handle/10394/14725/Sokhela_P.pdf

43. Statistics South Africa. (2020). Mid-year population estimates 2020 (Statistical Release No. P0302). Retrieved from http:// www.statssa.gov.za/publications/ P0302/P03022020.pdf

44. Stokburger-Sauer, N., Ratneshwar, S., \& Sen, S. (2012). Drivers of consumer-brand identification. International Journal of Research in Marketing, 29(4), 406-418. https://doi. org/10.1016/j.ijresmar.2012.06.001

45. Swanson, S. R., Gwinner, K., Larson, B. V., \& Janda, S. (2003). Motivations of college student game attendance and word-ofmouth behavior: the impact of gender differences. Sport Marketing Quarterly, 12(3), 151-162. Retrieved from https:// www.cabdirect.org/cabdirect/abstract/20033149707

46. Thomas, B. J., \& Sekar, P. C. (2008) Measurement and validity of Jennifer Aaker's brand personality scale for Colgate brand. Vikalpa: The Journal for Decision Makers, 33(3), 49-62. https://doi. org/10.1177/0256090920080304

47. Timberlake, C. (n.d.). Coach lacking brand personality seen as hindering growth. Retrieved from https://www.bloomberg.com/ news/articles/2013-01-24/coachlacking-brand-personality-seenas-hindering-growth-retail

48. Tsai, S. (2011). Strategic relationship management and service brand marketing. European Journal of Marketing, 45(7/8), 1194-1213. https://doi. org/10.1108/03090561111137679

49. Tuškej, U., Golob, U., \& Podnar, K. (2013). The role of consumerbrand identification in building brand relationships. Journal of Business Research, 66(1), 5359. https://doi.org/10.1016/j. jbusres.2011.07.022
50. Vahdati, H., \& Mousavi Nejad, S. H. (2016). Brand personality toward customer purchase intention: the intermediate role of electronic word-of-mouth and brand equity. Asian Academy of Management Journal, 21(2), 1-26. https://doi.org/10.21315/ aamj2016.21.2.1

51. Van Deventer, M. (2018) Modelling the factors that explain attitudes towards personal financial planning. International journal of Business and Management Studies, 10(2), 183193. Retrieved from https://www. sobiad.org/eJOURNALS/journal_ IJBM/arhieves/ijbm_2018_2_ek/ mv-deventer.pdf

52. Wilson, J. A. J., \& Grant, J. (2013). Islamic banking: A challenger to the classical marketing canon? Journal of Islamic Marketing, 4(1), 7-21. https://doi. org/10.1108/17590831311306327

53. Zikmund, W. G., \& Babin, B. (2013). Essentials of marketing research. (5th ed.). Beijing: SouthWestern Cengage Learning. 